
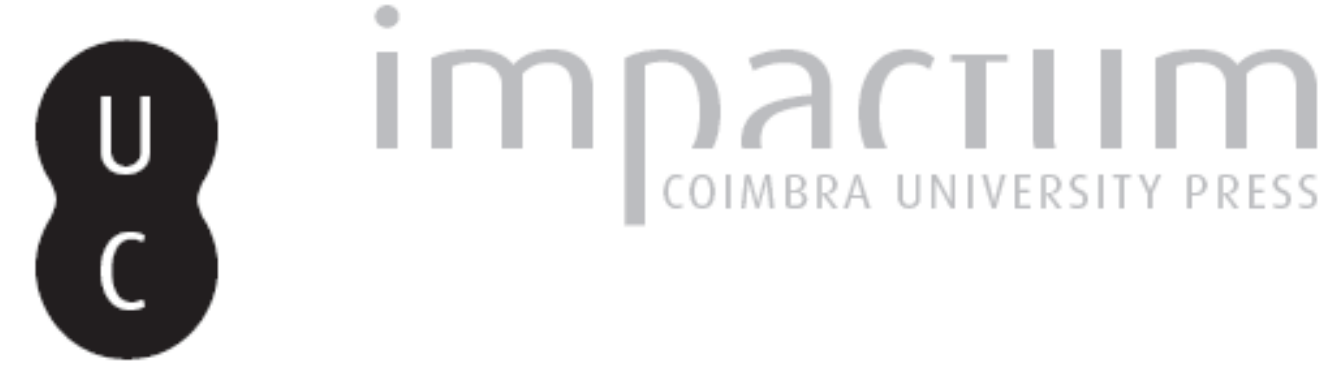

\title{
[Recensão a] Socratic and Platonic Political Philosophy: Practicing a Politics of Reading. By Christopher P. Long
}

\author{
Autor(es): $\quad$ Altman, William H. F.
}

Publicado por: $\begin{aligned} & \text { Sociedade Internacional de Platonistas; Imprensa da Universidade de } \\ & \text { Coimbra }\end{aligned}$

URL

persistente:

URI:http://hdl.handle.net/10316.2/38750

DOI: $\quad$ DOI:http://dx.doi.org/10.14195/2183-4105_15_7

Accessed : $\quad$ 26-Apr-2023 15:46:50

A navegação consulta e descarregamento dos títulos inseridos nas Bibliotecas Digitais UC Digitalis, UC Pombalina e UC Impactum, pressupõem a aceitação plena e sem reservas dos Termos e Condições de Uso destas Bibliotecas Digitais, disponíveis em https://digitalis.uc.pt/pt-pt/termos.

Conforme exposto nos referidos Termos e Condições de Uso, o descarregamento de títulos de acesso restrito requer uma licença válida de autorização devendo o utilizador aceder ao(s) documento(s) a partir de um endereço de IP da instituição detentora da supramencionada licença.

Ao utilizador é apenas permitido o descarregamento para uso pessoal, pelo que o emprego do(s) título(s) descarregado(s) para outro fim, designadamente comercial, carece de autorização do respetivo autor ou editor da obra.

Na medida em que todas as obras da UC Digitalis se encontram protegidas pelo Código do Direito de Autor e Direitos Conexos e demais legislação aplicável, toda a cópia, parcial ou total, deste documento, nos casos em que é legalmente admitida, deverá conter ou fazer-se acompanhar por este aviso.

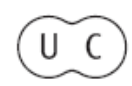


0

\section{Established 1989}

$\infty$ http://platosociety.org/

\section{Papers}

Thomas C. Brickhouse

Nicholas D. Smith

Socrates on the Emotions

Yosef Z. Liebersohn

Socrates, wake up! An analysis and exegesis of the "preface" in Plato's Crito (43a1-b9)

Nathalie Nercam

L'introduction problématique du Timée (17a-27a)

Christopher Moore

'Philosophy' in Plato's Phaedrus

Laura Candiotto

Plato's cosmological medicine in the discourse of Eryximachus in the Symposium. The responsibility of a harmonic technê

Anthony Hooper

Scaling the Ladder

Why the Final Step of the Lover's Ascent is a Generalizing Step

$\varangle$

Z
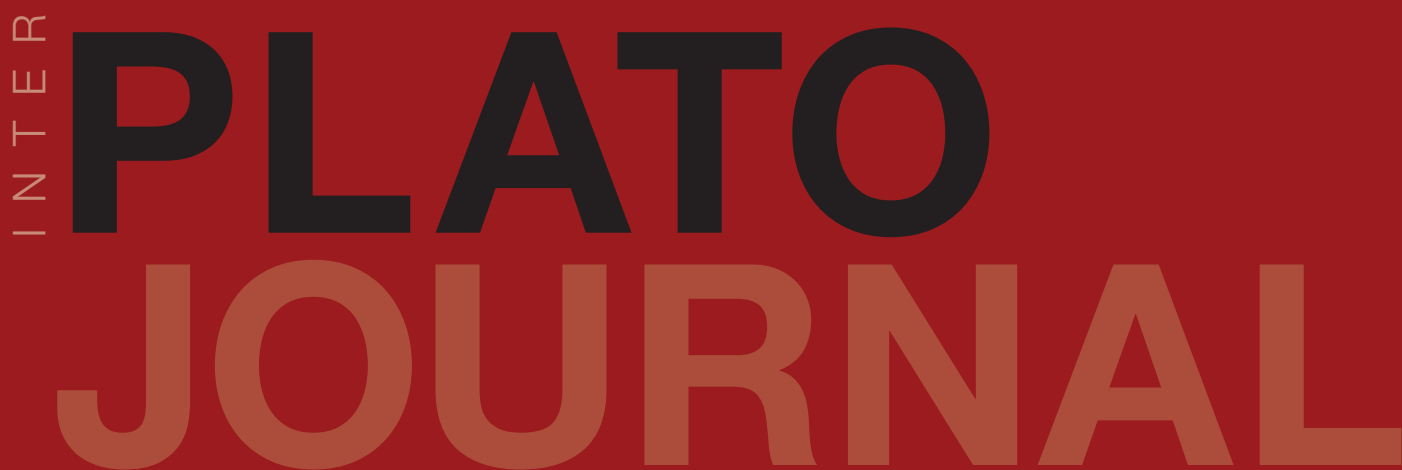

Société Platonicienne Internationale

Associazione Internazionale dei Platonisti

Sociedad Internacional de Platonistas

Internationale

Platon-Gesellschaft

Imprensa da

Universidade

de Coimbra

Coimbra

Universiy

Press 
Socratic and Platonic Political Philosophy: Practicing a Politics of Reading. By Christopher P. Long.

Cambridge University Press, Cambridge 2014, pp. xxi + 205. $\$ 90.00$ (hardback).

William H. F. Altman

Independent Scholar

whfaltman@gmail.com
Long's inspired and inspiring book is a veritable manifesto of the timeless relevance of the classics generally, and of Plato and Socrates in particular. Of Socrates' suggestion in the Apology that he be given free meals in the Prytaneum, Long writes (122): "By putting this suggestion into the mouth of Socrates, we are invited to consider the political implications of symbolically situating and nourishing the practice of philosophy at the very center of life." Serious students of Greek Philosophy are invited to reconsider occupying this center, and thus not only to read Long's book, but also to engage with it digitally (x-xi). Thanks to Long, potentially hackneyed phrases like "community of learners," "learning in the digital age," "collaborative learning," as well as both "advancing knowledge" and "transforming lives" are here given substance, tangible applicability, contemporary shape, and classical form (168-69): “The Platonic texts cultivate in us erotic habits of thinking and speaking attuned at once to the limits of $\log o s$ and to its power to transform our relationships to and with one another. Just as Socrates sought to open those he encountered to the erotic dimensions of the attempt to speak truth toward justice by curing them of their delusions of knowing and cultivating in them a concern for what is best, so too Platonic writing opens an erotic space between the text and the reader in which our delusions of certainty give way to a concern for questions capable of transforming the course of our lives and our relationships with others."

The book contains seven chapters, of which the middle five deal with the Protagoras, Gorgias, Phaedo, Apology of Socrates, and Phaedrus. The first chapter ("Politics as Philosophy") prepares the reader for Long's sense of the political (10): "Plato compels us to consider the extent to which philosophy itself is a political activity that requires us to ensure that all our relation- 
ships, be they public or private, are animated by an assiduous attempt to speak truth and seek justice." Arguing that Socrates has political obligations to both Hippocrates and the unnamed Companion in the dialogue's frame, Long's chapter on Protagoras, entitled "Crisis of Community," uses Socrates' threatened departure at the dialogue's center to indicate that what Protagoras offers is scarcely a dialogue-based community of learners (37): "if Hippocrates is to enter a community of education capable of nourishing his soul, it will need to be one that embodies the excellences of dialogue." Since the text where Socrates proclaims his possession of "the political art" is in Gorgias (521d6e4), the chapter on that dialogue ("Attempting the Political Art") is particularly important for Long's project $(6,8,12,17,42$, and 170), there he articulates the meaning of that art into three parts (61-62; cf. 160-61 and 175): "first, the ability to look into the nature of the one with whom one is engaged; second, the ability to act rooted in an understanding of what is responsible for the present condition of the one for whom one cares; and third, the ability to thoughtfully anticipate what is best for the soul of the one for whom one is concerned." The central fourth chapter ("The Politics of Finitude"), the book's self-conscious "fulcrum" (xix), argues that the transition in the Phaedo between "Socratic and Platonic Political Philosophy" is seamless (72): "Plato's poetic politics does with us precisely what Socrates sought to do with each individual he encountered." With the departure of Socrates as speaker, Plato as writer proves that (88-89): "reading itself can become a deeply political activity if, entering into dialogue with the text, we are willing to risk our opinions and possibilities in order to learn the political practice of living together in erotic relation to the truth fully cognizant, to the degree that we can be, of the ineluctable approach of your own concrete death.” The title of the chapter on the Apology ("Socratic Disturbances, Platonic Politics") uses, ingeniously, the four times the audience interrupts the speech to illustrate that even here is “Socrates' disquieting insistence that the city and each of its citizens take the practice of questioning up into their very character as an animating principle" (110), creating in the process a ceaseless political engagement that transgresses the customary boundaries (119): "By subverting the dichotomy between the private and public by appearing the same in both spheres, Socrates seeks to reinvigorate the political power of justice as an erotic principle capable of transforming human life in common, for justice is an ideal that, while remaining ultimately elusive, becomes politically powerful when it is permitted to animate the life of a community as a living question. To allow the question of justice to inform our relationships with one another in every sphere of human interaction is to begin not only to live a philosophical life but to practice Socratic politics." Since the Phaedrus emphasizes the written word from the start, "The Politics of Writing" allows Long to locate the Socratic education of Phaedrus at the dialogue's heart (163): "for the great advantage Platonic writing has over Socratic saying is precisely that it has been written and so is preserved in ways that invite each new generation to confront what is written in the attempt to come to meaningful terms with it in our human lives together. These texts hold us accountable to them and, through them, we are held accountable to one another if we are willing to engage in collaborative, imaginative readings and re-readings of the texts and if we allow what is encountered in such readings and re-readings to alter the course of our lives together." A final chapter ("Philosophy as Politics") brings this graceful book to a fitting conclusion (170): "Platonic, 
like Socratic, politics is the practice of erotic idealism."

The most creative aspect of the book is its use of the words "topology" and "topography," connected, of course, by the notion of "place." For Long, the place in question is broadly speaking "the learning community," a venue for dialogue, and for striving, collaboratively, for the good, the beautiful, and the just (56). The difference between the two words is that for Socrates, this place is opened up by his speeches, for Plato, by his writings (69-71). As a contribution to the study of Plato's dialogues, Long's book is a thoughtful meditation on the transition between Socratic speaking and Platonic writing: on how Plato, through a "topography" at once political and philosophical, sought to preserve intact, and indeed to immortalize (173, 176, and 178), the direct, immediate, erotic, and provocative power of Socratic "topology," understood as the ongoing practice of a deeply personal political art, practiced through dialogue in whatever place he might be, and equally dedicated to the betterment of any person he might meet. The reason the book culminates with the Phaedrus is because Socrates accomplishes the topological education of Phaedrus by means of reading Lysias together with him, and therefore embodies as well the dynamics of Platonic topography (131): "If the dialogue itself demonstrates the transformative power of collaborative reading, a reading of the dialogue attuned to what the written text shows will uncover the transformative power of Platonic writing itself. Such a reading, however, will need to be pursued in two intimately interconnected registers: (1) the topological register attends to the things Socrates says to Phaedrus and the manner in which Socrates' words turn Phaedrus toward the ideals of truth, beauty, and the good; (2) the topographical register attends to the ways
Platonic writing in the Phaedrus cultivates in its readers an orientation toward these same ideals." Maintaining both of these "registers" at once demands from the reader an openminded, erotic, and collaboratively dialogic ability for "practicing a politics of reading" (the book's subtitle) that allows Plato's topographical preservation of the Socratic paradigm of direct topological transformation (173): "If Platonic writing is political in a deep, Socratic sense, it enjoins an engaged politics of reading." Hence the "of" in the Apology of Socrates indicates at once the objective and subjective genitive (102n12): Socrates' defense of himself is at the same time Plato's defense of Socrates, and Long makes the Phaedo the fulcrum because its graphic account of Socrates' finitude is more than balanced by the dying man's eternal logos against misology (97): “The topography of Platonic politics, then, must be located in the figure of Socrates, the true Platonic erotic ideal, drawn in so compelling a way as to move us, generation after generation, to live a life and practice a death together animated by a common concern for justice and truth."

The only significant structural weakness in the book is that the previously published article on the Gorgias that becomes chapter 3 is poorly integrated into the flow of the argument as developed in the first two chapters; it fails to carry the reader forward, and occasionally betrays, disconcertingly, its extraneous origin. In an effort to explore the possibilities of "digital dialogue" in the context of what Long felicitously calls "hermeneutical imagination" (100), I registered on his website (and on the C. U. P. site dedicated to this book) a provocative comment about this chapter - i.e., the possibility that Callicles changed his mind after the speech of Socrates, and thereafter became the man we call "Plato" - and can report that the process is easy to navigate, and that Long 
takes such "notes" seriously, and responds to them promptly. Long's openness to dialogue is therefore by no means "talk," and his approach to the secondary literature, primarily in the notes, is uniformly respectful, and motivated by an ongoing effort both to learn and to create common ground. A more important weakness is that the word "erotic" is both overused and underdetermined, especially since Long bases his reading of Socrates' last words in the Phaedo - the critical moment in the transition between Socratic topology and Platonic topography (66-69; cf. 120) - on an article by Laurel Madison (66n 2 and 80n46), whose acknowledgment of a strictly tactical post-Platonism is as honest as it is illegitimate.

While "the just, the beautiful, and the good" are mentioned repeatedly (beginning on 5), the word "Ideas" in the Platonic sense appears only once, and only at the very end (185), where we learn, on David Roochnik's authority (185n42), that Plato "never claimed determinate knowledge of the Ideas." Instead, Long calls them "ideals," and thanks to the digital (i.e., searchable) version of the book available to all buyers (and even borrowers) through the Cambridge site, it is easy to prove that the word "elusive" is attached to these ideals with no less frequency than is the word "erotic" (the last section of the book is entitled "Erotic Ideals"). Consider how the words "elusive," "erotic," and "ideals" come together in a sentence near the end of the book that links Socratic topology to Platonic topography (183): "We experience the allure of Platonic dialogues even as they deploy distancing strategies of writing designed to diminish the aura of their own authority. In this sense, the written dialogues function much like the erotic ideals to which they so often appeal; for the dialogues present a figure of Socrates who is, like the ideals of justice, beauty, and the good themselves, at once alluring and elusive; and like our experience of those ideals, the allure of the Platonic Socrates is wholly saturated by an experience of his elusiveness." Even if we are ready to admit that "the problem of participation" is primarily embodied in Socrates' commitment to these ethical ideals - note here the influence Catherine H. Zuckert, Plato's Philosophers: The Coherence of the Dialogues (Chicago, IL: University of Chicago Press, 2009), 839; cf. 199n39, 484, and 804-5-it hardly seems likely that it was Plato's purpose to make them more elusive by connecting them to his topographically eternal, unforgettable, and vividly limned Socrates.

But even as "elusive," these "erotic ideals" are clearly central to Long's sense of Platonism, a sense, moreover, that he is determined not only to describe, but more importantly, to embody in his new administrative capacity. Especially since a broad array of Straussian or semi-Straussian scholars play so large a part in Long's scholarly imagination and background, it is refreshing to see that a fundamentally nondogmatic step beyond Strauss's dogmatic insistence on "knowledge of ignorance" continues to shape the field, thanks in large measure to the benign influence of Stanley Rosen and what might be called "Penn State Platonism." In addition to Charles Griswold and Ronna Burger - who guide Long through the Phaedrus - it is the influence of Jill Gordon (especially $5 \mathrm{n} 11$ and 73n25), Roslyn Weiss (especially 49n29), Marina McCoy (especially 105n16), Arlene Saxonhouse (especially 118), and Catherine Zuckert (passim) that enlivens and repeatedly humanizes these pages, and thanks to his ongoing commitment to a fundamentally dialogical philosophical politics, Long emerges in this book as both synthesizer and pioneer. Gone with the wind is dogmatic anti-idealism, and even though one would like to have seen a fuller discussion of what Long means by "erotic," it 
is difficult to imagine that he wouldn't need to distinguish it from the way it is deployed by Strauss, Seth Benardete, and Laurence Lampert. Given the origins of their approach in Nietzsche and Heidegger, it is interesting that the intellectual roots of Long's commitment to ideals that are at once elusive and transformative, philosophical and communitarian, both personally regulative and thoroughly political, also seems to have its roots in Germany, but in the school that Heidegger and his fellow Nazis effectively nullified: Marburg NeoKantianism.

Not only does Hans Vaihinger's characteristic als ob enter the narrative on 96 thanks to a quotation from James Wood, but the Marburg spirit is writ large on that page, a passage that also comes the closest to explaining what the word "erotic" means for Long: "These hypothetical ideals are erotic in a double sense. First, as ideals, they call us beyond the realities of our present modes of relation and draw us toward to new, more just and beautiful possibilities for human community. Second, however, as hypothetical, these ideals require the community to cultivate a culture of continuous critical questioning in order to determine how best to translate these ideals into new, more just and beautiful realities. Their erotic character is thus felt in their allure as ideals and in their elusiveness as hypotheses. These Socratic hypothetical ideals are much babbled about not because they are certain, eternal, and permanent but because they are capable of drawing those willing to seek them as if they surely existed into more just and truthful relation to one another. Plato writes this sober Socratic idealism into the text, and nowhere more eloquently than in the Phaedo, by setting it always into concrete ethical-political contexts in which the attempt to speak the truth is always animated by a desire to seek the Just, the Beautiful, and the Good. The topography of Platonic politics, then, must be located in the figure of Socrates, the true Platonic erotic ideal, drawn in so compelling a way as to move us, generation after generation, to live a life and practice a death together animated by a common concern for justice and truth." Given the fact that Long earned his Ph.D. at the New School, it is no surprise to find here the influence of Hannah Arendt, but that influence is, from the start, strictly dialectical (1-2; cf. 119n60). And even though Gadamer is cited frequently (xiv-xv, 83, 84n61, and 179-80), and his indirect influence through Drew Hyland is readily apparent (83n60; cf. chapter 4 as a whole), Long is really reviving - as what he calls "sober Socratic idealism" (96) - the moral seriousness, the ongoing political engagement, and the transformative role of necessarily elusive Ideas that flourished briefly in Marburg thanks, primarily, to Hermann Cohen.

But it is not the past that deserves the last word here: regardless of Long's pedigree with respect to intellectual history, it is his future impact that is the important thing. In the breakdown of the developmentalist paradigm (which Long never mentions), and in the interstices between the analytical anti-Platonism of G. E. L. Owen's students and the continental counterpart promulgated by the loyal students of Strauss, there has been emerging in the United States, topologically at Penn State, but topographically advanced in many other places too numerous to mention, a new consensus that Long has now been able to express in this elegant and compelling book. 